\title{
Transformative service research: a conceptual framework based on consumer's perspective
}

\author{
Veronica Ungaro, Laura Di Pietro, Maria Francesca Renzi, \\ Roberta Guglielmetti Mugion and Maria Giovina Pasca \\ Department of Business Studies, ROMA TRE University, Roma, Italy
}

TSR based on consumer's perspective

\begin{abstract}
Purpose - This study aims to investigate the consumer's perspective regarding the relationship between services and well-being, contributing to the knowledge base in transformative service research (TSR). More specifically the aim was to understand consumers' perceptions of the relationship between services and well-being and their views about how companies can contribute (directly and/or indirectly) to achieve the well-being.

Design/methodology/approach - To reach the research aim, the study adopts an explorative inductive design, carried out through a qualitative approach and grounded in 30 in-depth interviews with consumers. Findings - Service sustainability represents the fundamental characteristic that determines the service ability to be transformative, requiring the implementation of the triple bottom line dimensions: social, environmental and economic. It emerged that, in the consumer's mind, the service categories that present a stronger relationship between service and well-being are as follows: healthcare, financial and transport.

Originality/value - The paper proposes a conceptual framework to describe the consumer perspective of the services' transformative role in promoting well-being, providing a theoretical lens for conducting future research and continuing to expand transformative service research (TSR).
\end{abstract}

Keywords Transformative Service Research, Consumer well-being, Service sustainability, Service systems, Triple bottom line

Paper type Research paper

\section{Introduction}

The service industry is a growing sector (Edgar et al., 2017), and it can be said that services dominate the economies of the most advanced countries (Bitner and Brown, 2008).

We live and work within service systems, such as families or schools (Alkire et al., 2019) and consumers engage in services on a daily basis, interacting with a variety of service providers such as financial firms, healthcare providers and retailers (Anderson et al., 2013). Therefore, services have the potential to affect the social and economic world within which we live (Nasr and Fisk, 2019) and can have a positive or negative impact on consumer well-being (Anderson et al., 2013). In addition, services, given their pervasiveness, can also exert a significant environmental impact (Anderson et al., 2013).

An emerging movement, named transformative service research (TSR) aims to understand the role of services in enhancing consumer well-being (Rosenbaum et al., 2011).

Among the most important issues related to TSR is "designing and delivering services in a sustainable manner" and service sustainability has been identified as the most significant well-being-related subtopic (Ostrom et al., 2015).

(C) Veronica Ungaro, Laura Di Pietro, Maria Francesca Renzi, Roberta Guglielmetti Mugion and Maria Giovina Pasca. Published by Emerald Publishing Limited. This article is published under the Creative Commons Attribution (CC BY 4.0) licence. Anyone may reproduce, distribute, translate and create derivative works of this article (for both commercial and non-commercial purposes), subject to full attribution to the original publication and authors. The full terms of this licence may be seen at http:// creativecommons.org/licences/by/4.0/legalcode

Received 9 April 2021 Revised 17 June 2021 Accepted 20 July 2021 
TSR has been recognized as a research priority since 2010 (Ostrom et al., 2010). Over the years, there has been increasing interest in this field, but more studies are required in order to explore the relationship between well-being and services (Rosenbaum et al., 2011; Anderson et al., 2013; Anderson and Ostrom, 2015).

Given previous research opportunities, the present study aims to explore the consumer's perspective. Specifically, the purpose is to understand whether and how services are perceived by consumers as a means of contributing to their well-being. To achieve this aim, a qualitative study was adopted. In total, 30 in-depth interviews were performed to gain a broader view of the new and complex field of TSR and to deepen understanding of the consumer's perceptions about relationships between services and well-being.

Ultimately, this qualitative study answers the call for more research into TSR and contributes to the knowledge base in TSR by explaining the consumer perspective about the connection between services, service providers' activities and well-being, exploring the theme of service and sustainability and identifying the services which have the most impact on well-being from the consumer's point of view. The present research contributes to the existing literature by developing a conceptual framework that describes the consumer's perspective of services' transformative role in promoting well-being.

This paper is organized as follows. First, a literature review is provided in order to advance the aims of the research, and then the authors illustrate the methodology. The subsequent section provides the main results of the qualitative research, and then the authors discuss the main findings and illustrate their conceptual framework. Finally, conclusions, practical implications, limitations and recommendations for further research are presented.

\section{Literature review}

\section{Sustainability and sustainable development}

During the last 30 years, there have been remarkable advances in industrialization and development. It is recognized that such growth has caused problems regarding environmental, social and economic aspects, intensifying concerns about human quality of life and damage to the Earth's ecosystems (Lozano, 2008). Earth is heading for a point of no return (Carvalho et al., 2013) and society has become acutely conscious of the negative impacts of industry (Mota et al., 2015).

The concept of sustainable development (SD) has been identified as an approach that aims to reduce the impact of human activities (Lozano, 2008; Bilińska-Reformat et al., 2019). In 1987, the Brundtland Commission defined it as a "development that meets the needs of the present without compromising the ability of future generations to meet their own needs" (WCED, 1987). Elkington, in 1997, introduced the term "triple bottom line" (TBL) - a new vision that incorporated three dimensions in the concept of sustainability: environmental, economic and social. Recently, in 2015, the 193 United Nations (UN) member states formally adopted the 2030 Agenda for Sustainable Development and its 17 "sustainable development goals" (SDGs). The agenda is a concrete call to action with the aim of achieving the 17 SDGs by 2030 and represents a holistic approach to understand and address modern issues (UN, 2015).

Lubin and Esty (2010) specify sustainability as an "emerging megatrend." Today sustainability is viewed as an extremely important business goal by multiple stakeholders including customers, investors and policymakers. Companies around the world are increasingly aware of the business significance of sustainability (Sheth et al., 2011). They recognize that stakeholders' expectations about a company's commitment to sustainability has become a prerequisite for its legitimacy and competitiveness (Lubin and Esty, 2010; Murphy et al., 2013). At the same time, consumers can play a fundamental role in promoting sustainability because they can be agents of social change through their behaviors, and thus 
influence companies' activities and political institutions. Hence, analysis of the consumer's consciousness of sustainable behaviors and consumption is an important theme (Balderjahn et al., 2013).

Several authors have studied the concept of sustainability from the consumer's point of view. Choi and $\mathrm{Ng}$ (2011) explore the role of environmental and economic sustainability information in consumers' evaluations of companies, and their purchase intent, concluding that consumers do respond to multiple dimensions of sustainability. Balderjahn et al. (2013) developed a new, comprehensive approach to measuring "consciousness of sustainable consumption" (CSC) that incorporates the environmental, social and economic dimensions of sustainability. Barone et al. (2020) explored consumers' association with the term sustainability, identifying that better educated and younger consumers associate sustainability with the three dimensions: social, economic and environmental, but there are also consumers who are unaware of the whole concept.

Ostrom et al. (2015) indicate design service as a fundamental issue "to protect the environment" and incentivize customers and employees to "to take on roles that reduce a service's negative environmental impact." In addition, in Ostrom et al. (2015), Anderson points out that TSR examines, among others, the social and ecological consequences and benefits of service offerings and the impact of services on well-being and sustainability. In this dynamic context it is interesting to note the role of service science in pursuing sustainability, while fostering positive impact in social, environmental and economic spheres.

\section{The emergence of transformative service research}

Service research has been called on to explore how services can enhance human lives, especially since service organizations are often criticized for ignoring or harming consumer well-being (Rosenbaum et al., 2011; Kuppelwieser and Finsterwalder, 2016). TSR was first conceptualized by Anderson in 2010 (Anderson and Ostrom, 2015), and it is placed at the intersection between transformative consumer research and service research (Anderson et al., 2013; Ostrom et al., 2014; Kuppelwieser and Finsterwalder, 2016). TSR has been defined as "service research that centers on creating uplifting changes and improvements in the wellbeing of consumer entities: individuals (consumers and employees), communities and the ecosystem" (Anderson et al., 2011, 2013). In 2019, Nasr and Fisk suggested adding the term "relieving suffering" to the definition of TSR, extending it beyond "improving well-being." Their reasoning is that this second idea assumes that basic needs have already been satisfied, but in some cases, such as in the global refugee context, people are unable to access basic services.

The essential concept of TSR is that humans are surrounded by service systems that have an impact on their lives, influencing people's well-being in both positive and negative ways, and TSR aims to develop service strategies, innovation and design in order to build a better future (Fisk et al., 2016).

This emerging field was first identified as a key service research priority by Ostrom et al. (2010), and then TSR was recognized by influential service researchers as the highest priority (Ostrom et al., 2015; Nasr and Fisk, 2019). During the last years, the service community has shown increasing interest in this research area (Anderson and Ostrom, 2015).

TSR distinguishes itself from other service research in relation to the outcomes that it investigates (Alkire et al., 2019). TSR emphasizes the importance of indicators of increasing and decreasing well-being, like physical health, mental health, financial well-being, discrimination, literacy and access (Anderson and Ostrom, 2015). In contrast, traditional service research focuses on measures such as customer satisfaction and loyalty in order to understand factors that increase a firm's profitability (Rosenbaum et al., 2011).
TSR based on consumer's perspective

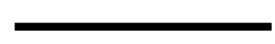


The World Health Organization (WHO) defined well-being in 1946 as "A state of complete physical, mental and social well-being and not merely the absence of disease or infirmity" (WHO, 1946; Edgar et al., 2017) and in 1997 as "a broad ranging concept affected in a complex way by the person's physical health, psychological state, personal beliefs, social relationships and their relationship to salient features of their environment" (WHO, 1997; Feng et al., 2019).

Within the TSR domain, Anderson et al. (2013), in their conceptual framework, theorized that the interaction between service entities and consumer entities within the macroenvironment affect the well-being outcomes of both. They identified two types of well-being outcomes: eudaimonic and hedonic. Eudaimonic well-being relates to the realization of human potential (Ryff, 1989). The authors provided a list of eudaimonic well-being dimensions such as access, literacy, better decision-making, individual and collective health, decreasing health and well-being disparities, consumer involvement, harmony, power, respect, support and social networks that can be applied at individual, collective and ecosystem levels. Hedonic well-being relates to the notion of happiness and pleasure (Diener and Lucas, 1999) and comprises happiness, life satisfaction and joy and the absence of negative effects such as tension, fear, strain and stress. Finally, hedonic well-being can be applied at individual and collective levels (Anderson et al., 2013). More recently, Rahman (2020), through a systematic literature review on 70 studies, identified the sources and categories of well-being from the TSR domain, providing a unified framework. In particular, he identified five sources of wellbeing (organization, individual, collective, service system and situation-driven) and two categories of well-being (improved (reduced) capacity and functioning and elevated (lowered) subjective appraisals of life conditions).

Examples of topics in TSR studies includes vulnerable consumers (i.e. Beatson et al., 2020; Ho et al., 2021), employee well-being (i.e. Rahman et al., 2020; Tuzovic and Kabadayi, 2021), refugee crisis (i.e. Aras et al., 2021; Gross et al., 2021) and service design (Rosenbaum et al., 2021). More recently, some studies attempted to understand the impact of COVID-19 on wellbeing (i.e. Finsterwalder and Kuppelwieser, 2020; Mollenkop et al., 2020). In Fisk et al. (2020) presented in their work a new movement named ServCollab that aims to support service research collaborations that seek to reduce human suffering and improve human well-being.

Some services, such as healthcare and education, are transformative by design, because they have a clear transformative mission. However, some services like retailing, entertainment and hospitality (Rosenbaum et al., 2011) have transformational potential even though they do not have an explicit transformative intent, because they might still impact people's well-being. Indeed, in the last years, it is possible to find some studies focused on this second kind of services, such as researches in the retailing sector (i.e. Gardiazabal and Bianchi, 2021; Naveed et al., 2021) or hospitality (i.e. Gallan et al., 2021).

Finally, TSR calls on service researchers who want to explore the relationship between services and individual and collective well-being from a micro to a macro level (Rosenbaum et al., 2011) and also have the opportunity to impact well-being (Anderson and Ostrom, 2015).

\section{Methodology}

In order to achieve the research's aim, a qualitative approach was planned, adopting an exploratory inductive research design (Eisenhardt, 1989). An empirical investigation was carried out through in-depth interviews with 30 consumers to study their perceptions regarding the complex phenomenon of the transformative role of services. Indeed, this qualitative methodology was considered appropriate for exploring the new and intricate field of TSR while providing useful insights for theory development and future research routes. 
Qualitative methods are particularly suitable for studying how a community or individuals "feel" about or interpret a specific issue (McCusker and Gunaydin, 2015; Boulay et al., 2014).

For this reason, the adopted qualitative method was guided by the inductive approach (Venkatesh et al., 2013), and in line with Bluhm et al. (2011), the methodology was designed to investigate fully how individual beliefs, thoughts and experiences connect services and wellbeing in the consumer's mind, with the aim of understanding individual perceptions and associated interpretations.

As suggested and utilized by several authors, (i.e. Dean and Indrianti, 2020; Lam and Bianchi, 2019; Edgar et al., 2017; Wiese et al., 2015), and considering the exploratory nature of the study, researchers decided to adopt semi-structured interviews composed of five guiding topics which were chosen, a priori, based on the literature analysis. In addition, ad hoc questions were developed by the interviewer during the interview allowing participants to analyze the topic in greater depth. The five topics are presented in Table 1, which provides a description and the linked literature for each one. The first topic analyzed is the well-being concept (1), which represents the starting point of the investigation. Then, a service focus was introduced to the interviewees with the transition from goods-dominant logic to servicedominant logic (2). After this general discussion on the new service logic, the interviewers initiated the core of the investigation, namely the relationship between service and well-being (3). For this topic, the respondents were free to propose their ideas on how services may contribute to well-being and social transformation. Accordingly, this was followed with a focus on the specific role played by the service providers in that relationship (4. Role of service providers). Finally, the interviews were concluded by asking which services consumers considered to have a stronger impact on, and contribution to, well-being (5. Relevant services).

Interviews were conducted from September to November 2019 and participants were selected through a snowball approach (Guido, 1999; Mugion et al., 2018; Lucia-Palacios

\begin{tabular}{|c|c|}
\hline Topic investigated & Description \\
\hline (1) Well-being concept & $\begin{array}{l}\text { Analysis of the meaning of "well- } \\
\text { being," including how it is described } \\
\text { and interpreted by consumers. } \\
\text { Potential faces of the concept are } \\
\text { investigated as well }\end{array}$ \\
\hline
\end{tabular}

(2) Transition from goodsdominant logic to servicedominant logic

(3) Relationship between services and well-being

(4) Role of service providers

(5) Relevant services
Introduction of the services perspective and analysis of what has changed from previous traditional logic based on goods

Exploration of how the relationship between services and well-being is perceived by the consumers. Analysis of the main aspects that influence this relationship for both providers and users

Analysis of the role played by service providers in acting to guarantee and pursue well-being

Identification of the most important services where the relationship between services and well-being plays the major role
Theoretical references

Diener and Lucas (1999), Diener (2000), Ryff (1989), World Health Organization (1946), Kuppelwieser and Finsterwalder (2016), Anderson et al. (2013), Ryan and Deci (2001), Waterman (1984), Anderson et al. (2013)

Vargo and Lusch (2004, 2006, 2008a, b)

Anderson and Ostrom (2015)

Anderson et al. (2013)

Rosenbaum et al. (2011)

Ostrom et al. (2010)

Anderson et al. (2013), Vargo and Lusch (2004, 2008a), Vargo (2011), Frow et al. (2014)

Rosenbaum et al. (2011)

Table 1 Description of the indepth investigated topics and related references
TSR based on consumer's perspective

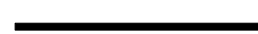


et al., 2016). The snowball sampling method has been largely used in qualitative research (Biernacki and Waldorf, 1981; Noy, 2008). In the current study, following the indications of Noy (2008), the authors selected the first respondent and asked him to identify one or two other informants. The researchers then contacted these individuals and asked each of them to provide one or two other contacts and so on until data saturation was reached. The final sample was composed of 18 male and 12 female participants, with age ranging from 25 to 45 years. To test the efficacy and validity of the guiding topics, a pilot interview was carried out.

Data saturation principles for theory-based interview studies were applied (Francis et al., 2010). Data saturation refers to the extent to which predetermined themes are adequately represented in the data (Lam and Bianchi, 2019). The decision to collect more data is based on the non-emergence of new themes (Saunders et al., 2018). Hence, the data collection continued for 30 interviews until data saturation was reached. The sample size is appropriate for qualitative analysis where the analysis of a wider sample (more than 30) may become too complex to manage (Boddy, 2016), and indeed Marshall et al. (2013) suggest a range of 15-30 for qualitative interviews (Arasli and Arici, 2019).

The interviews were recorded and transcribed and, once this process was concluded, the authors analyzed the transcriptions through content analysis. Text analysis software (MAXQDA18, VERBI Software GmbH, Berlin, Germany) was utilized to study, code and interpret each phrase. To guarantee the rigor of the research, multiple investigators were involved in the coding activity (Barratt et al., 2011; Di Pietro et al., 2018).

As suggested by Altinay et al. (2014) and Arasli and Arıc1 (2019), similar concepts were coded and grouped into categories and first-order issues were identified. Subsequently, data were interpreted and classified by the researchers in second-order themes. As observed by Aal et al. (2016), through a thematic analysis (Luborsky, 1994) it is possible to detect categories that can catch and represent the "nature of each individual view" (Aal et al., 2016). Finally, second-order themes were merged in aggregate dimensions.

\section{Results}

In total, 30 in-depth interviews lasting from $45 \mathrm{~min}$ to $1 \mathrm{~h}$ were performed face-to-face. The sample was composed of 18 male and 12 female participants, with age ranging from 25 to 45 years.

The results are presented as follows. First, services considered as priorities for their ability to contribute to well-being are analyzed. Second, the detected first-order issues are described. Third, the second-order themes are introduced and outlined. Finally, the explanatory relevant dimensions are discussed.

\section{Type of service and contribution to well-being}

During the interviews, most respondents identified more than one service, but it emerged that the three which were most frequently mentioned and perceived by the respondents as presenting a stronger relationship between service and well-being were healthcare (Freq. 19), transport (Freq. 13) and financial services (Freq. 9). In the context of healthcare services, cleanliness, a professional and competent operator and an easily accessible, fast and affordable service were identified by interviewees as the main features that can impact the well-being of end-users. In the case of transport services, the respondents highlighted that well-being can be guaranteed by a transport network that connects the whole city with punctuality and reliability, safety, cleanliness and affordability. According to interviewees, financial services can contribute to well-being when they are fast, customized, accessible, online and have professional operators. Supplementary mention was made of the services as follows: public services, education, tourism and social services. 
Identification of first-order issues

The authors analyzed the transcriptions and, utilizing the coding activities and their interpretations, they categorized the opinions and thoughts of respondents into 12 first-order issues that are reported in Table 2 together with two examples of quotations for each issue.

The central issue that emerged from the interviews is the importance of service sustainability and its connection with the well-being. In fact, it is seen as the fundamental service feature required ensuring human welfare.

During the research, interviewees provided different definitions of well-being. Some respondents related the concept to personal psychological, physical and economic conditions and the simplification of the daily life of individuals. Others identified well-being as a broader concept incorporating future generations, political stability and society's economic growth. Another important aspect that emerged is the need for government regulation to make services safe, reliable and transparent.

Respondents expressed the need to preserve biodiversity and non-renewable resources for future generations. In order to reach this goal, a value was given to collective actions. From the respondents' point of view, cooperation between citizens can help achieve well-being in society and improve the human quality of life, and they cited, for example, services like carsharing and bike-sharing.

Respondents stressed the role of companies in ensuring community well-being. They also affirmed that firms must satisfy the needs of not only of the final customers, but also of their employees. Emphasis was placed on the role of both internal and external communication. The objective of internal communication must be to disseminate corporate culture and educate managers to adopt sustainable behaviors. The aim of external communication must be to inform the final consumer about the company's sustainable actions and their commitment to enhancing social well-being.

In addition, interviewees identified innovation and new technologies as fundamental practices and suggested that activities such as recycling and reuse could be further developed to reduce environmental impacts and apply a circular economy model.

\section{Detection of second-order themes and aggregate dimensions}

Starting with analysis of the identified first-order issues and their content, the researchers grouped them and detected second-order themes characterizing the relation between services and well-being. In particular, the authors identified six main themes (Table 3).

The first theme, individual well-being, included issues that are connected with the respondents' vision of well-being as a concept relating to their personal and unique conditions (psychophysical stability, economic stability and simplification of daily life). The second theme, collective well-being, contains issues where respondents expressed well-being as a broad concept embracing the whole of society (future generations and political and economic stability). The third theme, institutional arrangements, connects with the need to guarantee, through regulation, safe, transparent and reliable services. The fourth theme, environmental well-being, incorporates issues associated with the need to preserve the environment and actions that can help to achieve this aim (preservation of biodiversity/resources and consumer cooperation). The fifth theme, service providers' role, refers to issues related to respondents' vision regarding the role of companies in ensuring community welfare (employees and end-users, communication and education and innovation and technology). The last theme, service sustainability, seems to link directly to the sustainability issue and indirectly connect with all the other themes.

Finally, the analysis of existing relations among the second-order themes led to the definition of four aggregate dimensions that describe and synthesize the transformative power of services in contributing to well-being. Four dimensions were detected: social,
TSR based on consumer's perspective

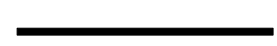


Issue Quotation

Sustainability

Safety, reliability and transparency

Communication and education

Economic stability

Preservation of biodiversity/ resources

Simplification of daily life

Future generations

Innovation and technology
(1) "I believe that sustainability is the most important social benefit to pursue, improving the lives of human beings, plants, animals, society and the ecosystem" (Respondent 3)

(2) "I think it all comes down to sustainability. What has happened in Australia and in Amazonia in the last months is incredible. The companies will have to do something about it, otherwise there will be an apocalyptic scenario" (Respondent 7)

(1) "A service must be reliable and secure and regulations should ensure it" (Respondent 15)

(2) "I believe that we should have regulations that oblige companies to manage their services in a better way and to be transparent and promote social welfare" (Respondent 20)

(1) "To increase social well-being, companies can organize communication campaigns to raise consumer awareness, in addition to those aimed at their employees" (Respondent 30)

(2) "Companies should educate consumers and employees through communication to generate more conscious consumption" (Respondent 10)

(1) "In my opinion, well-being is the opportunity to guarantee a proper economic condition for myself and my family" (Respondent 1)

(2) "I think that well-being means my economic stability and that of my family" (Respondent 8)

(1) "The preservation of the environment today is a central theme, and therefore acts in respect of the planet and future generations. Safeguard the surrounding environment and all beings" (Respondent 9)

(2) "The conservation of natural habitats and non-renewable resources is certainly important in order to guarantee the same rights to future generations" (Respondent 12)

(1) "A service must necessarily be useful for everyday life; an example is efficient public transport" (Respondent 4)

(2) "A service must simplify the personal life of each of us. For example, a service needs to be customized to provide what the user needs" (Respondent 25)

(1) "I think of my personal well-being but also of the community and it's important to guarantee to meet the needs of both me and future generations" (Respondent 13)

(2) “... It's also important to guarantee the same rights for future generations and safeguard their well-being" (Respondent 2)

(1) "I think that managers need to adopt sustainable attitudes. And then they need to promote a sharing culture, with the digitization and use of more technological methods, which allow us to save and recycle resources" (Respondent 11)

(2) "To improve environmental well-being, managers could study new methods to avoid their impact on the environment and on society. For example, to improve a service, I would try to apply a circular economy system or implement policies of reuse and recycling of raw materials. Of course, it is important to convey these policies not only internally but also externally in order to raise awareness among citizens and consumers" (Respondent 16)
Table 2.

First-order issues and quotations 


\section{Issue}

Employees and end-users

Political and economic stability

Consumer Cooperation

Psychophysical stability

Note(s): Translated from Italian by the authors

\section{Quotation}

(1) "A company, in order to guarantee social well-being, must guarantee the well-being of its human resources, who are now a fundamental element of a company" (Respondent 5)

(2) "I would like to see companies that take into account not only profit but also the social well-being of citizens; I would like to see a more united and less consumerist community" (Respondent 21)

(1) "It makes me think of being comfortable with oneself and with others. Let's say I thought more than anything that well-being is something individual, but I now think it can also be extended to the community, like having political and economic stability in the country" (Respondent 18)

(2) "It is important that economic well-being and social tranquillity are guaranteed, with the possibility of living in a country that is stable politically and economically" (Respondent 24)

(1) "I believe that we are going towards a new globalization, a new way of living. Collective actions can lead to a lesser impact on the environment and improve our well-being" (Respondent 24)

(2) "Sharing services and consumers' collaboration can help reduce environmental impacts" (Respondent 16)

(1) "Well-being in my opinion means having a psychophysical stability that allows you to feel good with yourself and with others" (Respondent 15)

(2) "For me well-being is linked to a situation of stability such as the fact that there is something to eat, there is good health" (Respondent 29)
TSR based on consumer's perspective

\begin{tabular}{|c|c|c|}
\hline Dimension & Theme & Issue \\
\hline \multirow[t]{5}{*}{ Social transformation } & Individual well-being & $\begin{array}{l}\text { Psychophysical stability } \\
\text { Economic stability }\end{array}$ \\
\hline & & Simplification of daily life \\
\hline & Collective well-being & Future generations \\
\hline & & Political and economic stability \\
\hline & Institutional arrangements & Safety, reliability and transparency \\
\hline Environmental transformation & Environmental well-being & $\begin{array}{l}\text { Preservation of biodiversity/resources } \\
\text { Consumer cooperation }\end{array}$ \\
\hline Economic transformation & Service providers' role & $\begin{array}{l}\text { Communication and education } \\
\text { Innovation and technology } \\
\text { Emplovees and end-users }\end{array}$ \\
\hline Service sustainability & Service sustainability & Sustainability \\
\hline
\end{tabular}

Table 3.

Relations between aggregate dimensions, second-order themes and related first-order issues

environmental, economic attitude and service sustainability (Table 3). An explanation and interpretation of the four dimensions is presented in the following section.

\section{Discussion and theoretical framework}

The current study detects three significant services where the relationship between service and well-being seemed to play a major role in the respondents' minds: healthcare, financial and transport services. Healthcare is defined as a service that is transformative by design and has received attention from different research fields (Rosenbaum et al., 2011). There are already studies concerning the connection between financial services and well-being (Anderson et al., 2013; Brüggen et al., 2017). However, transport seems to emerge as a new 
service linked with consumer's well-being. Moreover, respondents provided a list of the main features for each type of service that, in their opinion, have a direct impact on the well-being.

As a result of the transcription analysis, the authors categorized the respondents' opinions into 12 first-order issues, grouped in 6 themes, which are related to 4 dimensions.

From the analysis it emerges that service sustainability is identified as the essential issue to guarantee the well-being. This is probably in line with increased social consciousness of the negative impacts of industry (Mota et al., 2015) and sustainability being recognized as an extremely important business goal by customers, investors and policymakers (Sheth et al., 2011). However, although there are several studies analyzing the concept of sustainability from the customer's point of view (Choi and Ng, 2011; Balderjahn et al., 2013; Sheth et al., 2011), there is a lack of discussion on sustainability in TSR (Guyader et al., 2019). Shirahada and Fisk (2011) define service sustainability as "satisfying the needs of current providers and recipients to engage in mutual value co-creation without decreasing the quality of future value co-creation."

The analysis of the results reveals that service sustainability is strongly linked with the other three dimensions identified: social, environmental and economic transformation. This finding highlights the existence of a connection between TSR and the triple bottom line (TBL). Indeed, the TBL (Elkington, 1997) recognizes that organizations have to consider the multi-dimensional impact of their strategies. In light of this, it is possible to apply the lens of the TBL to better explain service sustainability.

The social transformation dimension is connected to the social sustainability dimension. The social aspect of sustainability is a non-economic form of wealth concerned with the wellbeing of people and communities (Choi and $\mathrm{Ng}$, 2011). Indeed, the social dimension relates to human aspirations: equity, inclusion and health (Kuhlman and Farrington, 2010). The social environment aims to safeguard the basis of the existence of individuals, and it can deteriorate just like the natural environment (Pawłowski, 2008). The Global Reporting Initiative (GRI) defines the social dimension of sustainability as one that "concerns the impacts the organization has on the social systems within which it operates" (GRI, 2013). During the interviews, respondents emphasized different interpretations of well-being that authors categorized into two concepts: individual and collective well-being (Anderson et al., 2013). Moreover, interviewees recognized the important role of all potential actors, especially policymakers, in ensuring transparency, reliability and safety during service provision (institutional arrangements). Norms, rules and habits need to be respected but also changed as required to foster the service's power to drive transformation. This is in accordance with Anderson et al. (2013) who affirm that in TSR it is crucial to understand which actions both businesses and governments should plan in order to increase service sustainability. In addition, as observed by Di Pietro et al. (2018), through institutionalized norms and rules that create shared meanings (Vargo and Lusch, 2016), it is possible to create values that resonate (Edvardsson and Enquist, 2009, 2011) with the community. In accordance with the social dimension features identified by authors so far (Choi and Ng, 2011; Pawłowski, 2008; Kuhlman and Farrington, 2010; GRI, 2013), they classified the themes individual and collective well-being (Anderson et al., 2013) and institutional arrangements (Anderson et al., 2013; Edvardsson and Enquist, 2009, 2011; Vargo and Lusch, 2016; Di Pietro et al., 2018) into the social transformation dimension.

The environmental transformation dimension of service sustainability refers to the environmental aspect that, as described in the literature, relates mainly to the conservation of nature and biodiversity (Goodland, 1995; Lozano, 2008; Pawłowski, 2008; Morelli, 2011). Moreover, the conservation of nature is linked indirectly with the shape of the spatial order, and, in this way, it is also connected with social relations between people (Pawłowski, 2008). Environmental sustainability has become increasingly important to the consumer since the 1980s when natural issues such as climate change and rising sea levels gained urgency (Choi 
and $\mathrm{Ng}$, 2011). It is recognized that services given their pervasiveness, can have a large environmental impact (Guyader et al., 2019). In their work, Guyader et al. (2019) focused their attention on the notion of green service that they defined as "service provision aimed at improving the well-being of the natural ecosystem in order to better the quality of life of present and future generations." Therefore, they stated that green service focuses not only on satisfying customer needs but also on improving environmental benefits. In the current research study, respondents observed the relevance of ensuring the preservation of nonrenewable resources and the natural ecosystem for future generations through the service provision, in accordance with the main definition of sustainable development (SD) (WCED, 1987) and the importance of cooperation between citizens in order to achieve society's wellbeing (Pawłowski, 2008). Authors grouped these findings in the concept of environmental well-being (Pawłowski, 2008; Guyader et al., 2019), and considering the environmental sustainability concept definition (Goodland, 1995; Lozano, 2008; Pawłowski, 2008; Morelli, 2011), this theme was included in the environmental transformation dimension.

The economic transformation dimension is linked with the economic impact of sustainability. Due to the global economic recession, consumers and society, fearing job losses, insecurity and financial risks have become increasingly concerned with economic sustainability (Choi and Ng, 2011). In their work, Sheth et al. (2011) affirmed that the economic dimension of sustainability is composed of two aspects: the first one is related to the financial performance of the firm; the second is related to "economic interests of external stakeholder, such as a broad-based improvement in economic well-being and standard of living"; hence, it is linked with a firm's contribution to society (Choi and Ng, 2011). In the present study, it emerges that companies are viewed as fundamental actors in ensuring community well-being (Anderson et al., 2013). Respondents identified the importance of satisfying the needs of both end-user and employee. Some studies have already analyzed employee well-being and/or its connection with consumer well-being (Anderson et al., 2013; Sharma et al., 2016; Huang and Lin, 2020). Moreover, interviewees enlightened the relevance of internal and external communication and seen service providers as drivers of innovation. Even the firms themselves recognize that their legitimacy and competitiveness is based on stakeholders' expectations about the company's commitment to sustainability (Lubin and Esty, 2010; Murphy et al., 2013). Authors classified the previous concepts in the service provider's role theme, and in accordance with the literature analyzed (Lubin and Esty, 2010; Sheth et al., 2011; Choi and Ng, 2011; Anderson et al., 2013; Murphy et al., 2013), it was grouped in the economic transformation dimension.

To synthesize the presented findings, a conceptual model is proposed in Figure 1. In accordance with Anderson et al. (2013), the analysis of consumers' perceptions confirmed the

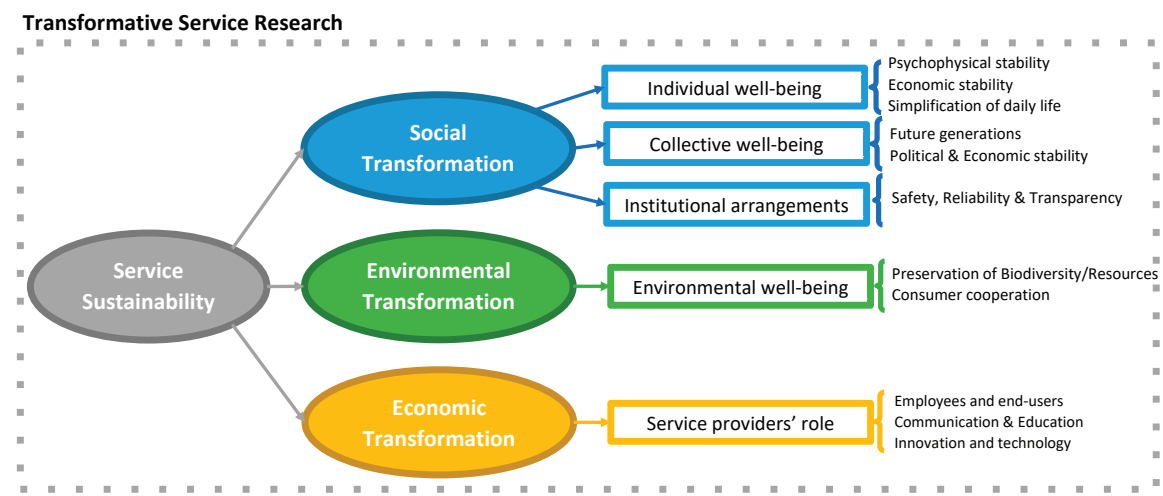

TSR based on consumer's perspective

$+$


existence of a strong relationship between service sustainability and fostering TSR. Service sustainability emerged as the fundamental characteristic determining the ability of the service to be transformative and to have an impact on the well-being (Ostrom et al., 2015). Moreover, the results highlight that service sustainability integrates the TBL, namely social, environmental and economic dimensions, to achieve the well-being. The three dimensions elucidate the spheres in which the transformation should be expressed.

Social transformation describes the need to pursue both individual and collective wellbeing (Anderson et al., 2013) with service provision. Furthermore, services must be provided following the principles of safety, reliability and transparency, consistent with institutional arrangements (Edvardsson and Enquist, 2009, 2011; Anderson et al., 2013; Vargo and Lusch, 2016; Di Pietro et al., 2018). Environmental transformation is characterized by the ability of the service to guarantee environmental well-being, through preservation of resources and invitations for citizens to act to reduce their impact (Goodland, 1995; Lozano, 2008; Pawłowski, 2008; Morelli, 2011; Guyader et al., 2019).

Economic transformation refers to service providers' ability to innovate the service provision by introducing new sustainable technologies and take care of both workers and end-users, by educating them and fostering sustainable development (SD) (Lubin and Esty, 2010; Sheth et al., 2011; Choi and Ng, 2011; Anderson et al., 2013; Murphy et al., 2013; Sharma et al., 2016; Huang and Lin, 2020).

\section{Conclusion and implications}

Services dominate the economies of the world and can create serious environmental impact (Bitner and Brown, 2008; Anderson et al., 2013; Nasr and Fisk, 2019). Since TSR has been identified as a research priority (Ostrom et al., 2010, 2015) and service sustainability has been appointed as the most significant well-being-related sub-topic (Ostrom et al., 2015), we have responded to the call to broaden this field and contribute to understanding and exploring issues related to the well-being (Rosenbaum et al., 2011; Anderson et al., 2013; Anderson and Ostrom, 2015). The present research contributes to the knowledge base in TSR by developing an empirical study and explaining the consumer's perspective of the relationship between services, service providers' activities and well-being.

First, the present research identifies healthcare, transport and financial services as the services which, from the consumer's point of view, have the strongest impact on well-being. Second, the present paper contributes to the existing literature by proposing a conceptual framework aimed at elucidating how services foster the transformation to contribute to the well-being. A relationship between TSR and the TBL emerges in the study, specifically which respondents believed service sustainability to be the main aspect that could influence consumer well-being, particularly in the three transformative dimensions defined by the TBL: social, environmental and economic.

Moreover, the study supports the progress of the 2030 Agenda by contributing to SDG 12 "Ensuring sustainable consumption and production patterns" by emphasizing the pivotal importance attributed by consumers to service sustainability in promoting well-being.

In addition, the present research suggests some practical implications. Our research has shown that, from the consumer's viewpoint, service providers play a fundamental role in ensuring sustainability and well-being. Respondents seem to attribute to organizations a heavy responsibility for the effects of their activities on society's welfare. Therefore, industries should be careful about the impact of their actions and find ways to communicate their commitment to sustainable development (SD) and the 2030 Agenda. Accordingly, for companies, it becomes crucial to implement strategies that suitably direct their actions, maximizing the organization's positive impact while minimizing its negative impact on stakeholders and the environment. In the consumer's mind, innovation and technology could 
both contribute to alleviating the consequences of human activities on the environment and the community. For this reason, policymakers, companies and citizens should collaborate in identifying new tools and strategies to ensure a more sustainable society. In addition, the interviewees stressed the duty of the government to guarantee safe and transparent services. Therefore, policymakers should strive to develop regulations to control companies' activities and ensure proper service provision. Finally, governments could also launch awarenessraising campaigns to help the population fully understand their role in achieving the common goal that is human well-being.

This analysis was developed before the global health emergency caused by the spread of the COVID-19 disease and, in our opinion, the pandemic has made even more evident the imperative to understand how to improve and contribute to human welfare. COVID-19 has undoubtedly shown that all humans and nations are interconnected, forcing us to rethink ways of living and consuming.

\section{Limitations and future research}

This exploratory qualitative research study contributes to existing knowledge with the proposal of a conceptual framework that provides a theoretical lens for conducting future research and further investigations. Despite this, as with all empirical research, the present study has certain limitations. First, the research involves only one country. Thus, future research should extend the study to a larger sample selected from different geographical areas to understand if the vision of the relationship between services and well-being changes from group to group in different social contexts. Second, the study adopted a qualitative method to inform theory and provide a lens for further investigations. Accordingly, future research should continue the analysis by adopting quantitative methods for testing the model. Moreover, future research should investigate whether consumers in other countries identify different services where the relationship between service and well-being plays a major role. For example, there could be different views regarding transport services in different cities. In future research, it may be profitable to explore fully the reasons behind consumers' perceptions of service sustainability as the most significant feature in making a service transformative. In addition, the analysis was carried out before COVID-19 emergency so future research should explore if and how consumers' viewpoints have changed. Finally, future research should also focus on investigating service providers' perspectives and the entrepreneur's point of view regarding the transformative role of services.

\section{References}

Aal, K., Di Pietro, L., Edvardsson, B., Renzi, M.F. and Mugion, R.G. (2016), "Innovation in service ecosystems: an empirical study of the integration of values, brands, service systems and experience rooms", Journal of Service Management, Vol. 27 No. 4, pp. 619-651, doi: 10.1108/ JOSM-02-2015-0044.

Alkire, L., Mooney, C., Gur, F.A., Kabadayi, S., Renko, M. and Vink, J. (2019), “Transformative service research, service design, and social entrepreneurship: an interdisciplinary framework advancing wellbeing and social impact", Journal of Service Management, Vol. 31 No. 1, pp. 24-50, doi: 10.1108/JOSM-05-2019-0139.

Altinay, L., Brookes, M., Yeung, R. and Aktas, G. (2014), "Franchisees' perceptions of relationship development in franchise partnerships", Journal of Services Marketing, Vol. 28 No. 6, pp. 509-519, doi: 10.1108/JSM-09-2013-0240.

Anderson, L. and Ostrom, A.L. (2015), "Transformative service research: advancing our knowledge about service and well-being”, Journal of Service Research, Vol. 18 No. 3, pp. 243-249, doi: 10. 1177/1094670515591316. 
Anderson, L., Ostrom, A.L. and Bitner, M.J. (2011), "Surrounded by services: a new lens for examining the influence of services as social structures on well-being", Working Study, WP Carey School of Business, Arizona State University, Phoenix, AZ.

Anderson, L., Ostrom, A.L., Corus, C., Fisk, R.P., Gallan, A.S., Giraldo, M., Mende, M., Mulder, M., Rayburn, S.W., Rosenbaum, M.S., Shirahada, K. and Williams, J.D. (2013), "Transformative service research: an agenda for the future", Journal of Business Research, Vol. 66 No. 8, pp. 1203-1210, doi: 10.1016/j.jbusres.2012.08.013.

Aras, N.E.G., Kabadayi, S., Ozeren, E. and Aydin, E. (2021), "Right to health and access to health-care services for refugees in Turkey", Journal of Services Marketing, Vol. ahead-of-print No. aheadof-print, doi: 10.1108/JSM-06-2020-0256.

Arasli, H. and Arıc1, H.E. (2019), "The art of retaining seasonal employees: three industry-specific leadership styles", The Service Industries Journal, Vol. 39 Nos 3-4, pp. 175-205, doi: 10.1080/ 02642069.2018.1478412.

Balderjahn, I., Buerke, A., Kirchgeorg, M., Peyer, M., Seegebarth, B. and Wiedmann, K.P. (2013), "Consciousness for sustainable consumption: scale development and new insights in the economic dimension of consumers' sustainability”, AMS Review, Vol. 3 No. 4, pp. 181-192, doi: 10.1007/s13162-013-0057-6.

Barone, B., Rodrigues, H., Nogueira, R.M., Guimarães, K.R.L.S.L.D.Q. and Behrens, J.H. (2020), "What about sustainability? Understanding consumers' conceptual representations through free word association”, International Journal of Consumer Studies, Vol. 44 No. 1, pp. 44-52, doi: 10.1111/ ijcs.12543.

Barratt, M., Choi, T.Y. and Li, M. (2011), "Qualitative case studies in operations management: trends, research outcomes, and future research implications", Journal of Operations Management, Vol. 29 No. 4, pp. 329-342, doi: 10.1016/j.jom.2010.06.002.

Beatson, A., Riedel, A., Chamorro-Koc, M., Marston, G. and Stafford, L. (2020), "Increasing the independence of vulnerable consumers through social support", Journal of Services Marketing, Vol. 34 No. 2, pp. 223-237, doi: 10.1108/JSM-09-2019-0327.

Biernacki, P. and Waldorf, D. (1981), "Snowball sampling: problems and techniques of chain referral sampling", Sociological Methods and Research, Vol. 10 No. 2, pp. 141-163, doi: 10.1177/ 004912418101000205.

Bilińska-Reformat, K., Kucharska, B., Twardzik, M. and Dolega, L. (2019), "Sustainable development concept and creation of innovative business models by retail chains", International Journal of Retail and Distribution Management, Vol. 47 No. 1, pp. 2-18, doi: 10.1108/IJRDM-04-2017-0071.

Bitner, M.J. and Brown, S.W. (2008), "The service imperative”, Business Horizons, Vol. 51 No. 1, pp. 39-46, doi: 10.1016/j.bushor.2007.09.003.

Bluhm, D.J., Harman, W., Lee, T.W. and Mitchell, T.R. (2011), "Qualitative research in management: a decade of progress”, Journal of Management Studies, Vol. 48 No. 8, pp. 1866-1891, doi: 10.1111/j. 1467-6486.2010.00972.x.

Boddy, C.R. (2016), "Sample size for qualitative research", Qualitative Market Research: An International Journal, Vol. 19 No. 4, pp. 426-432, doi: 10.1108/QMR-06-2016-0053.

Boulay, J., de Faultrier, B., Feenstra, F. and Muzellec, L. (2014), "When children express their preferences regarding sales channels: online or offline or online and offline?", International Journal of Retail and Distribution Management, Vol. 42 Nos 11/12, pp. 1018-1031, doi: 10.1108/ IJRDM-05-2014-0055.

Brüggen, E.C., Hogreve, J., Holmlund, M., Kabadayi, S. and Löfgren, M. (2017), "Financial well-being: a conceptualization and research agenda", Journal of Business Research, Vol. 79, pp. 228-237, doi: 10.1016/j.jbusres.2017.03.013.

Carvalho, A., Matos, H.A. and Gani, R. (2013), "SustainPro-a tool for systematic process analysis, generation and evaluation of sustainable design alternatives", Computers and Chemical Engineering, Vol. 50, pp. 8-27, doi: 10.1016/j.compchemeng.2012.11.007. 
Choi, S. and Ng, A. (2011), "Environmental and economic dimensions of sustainability and price effects on consumer responses", Journal of Business Ethics, Vol. 104 No. 2, pp. 269-282, doi: 10. 1007/s10551-011-0908-8.

Dean, A. and Indrianti, N. (2020), "Transformative service research at the BoP: the case of Etawa goat farmers in Indonesia”, Journal of Services Marketing, Vol. 34 No. 5, pp. 665-681, doi: 10.1108/ JSM-07-2019-0251.

Di Pietro, L., Edvardsson, B., Reynoso, J., Renzi, M.F., Toni, M. and Mugion, R.G. (2018), “A scaling up framework for innovative service ecosystems: lessons from Eataly and KidZania”, Journal of Service Management, Vol. 29 No. 1, pp. 146-175, doi: 10.1108/JOSM-02-2017-0054.

Diener, E. (2000), "Subjective well-being: the science of happiness and a proposal for a national index", American Psychologist, Vol. 55 No. 1, pp. 34-43, doi: 10.1037/0003-066X.55.1.34.

Diener, E. and Lucas, R.E. (1999a), "Personality and subjective well-being", Well-being: Foundations of Hedonic Psychology, Russel Sage Foundation, New York, pp. 213-229.

Diener, E. and Lucas, R.E. (1999b), "11 personality and subjective well-being”, Well-being: Foundations of Hedonic Psychology, p. 213.

Edgar, F., Geare, A., Saunders, D., Beacker, M. and Faanunu, I. (2017), "A transformative service research agenda: a study of workers' well-being”, The Service Industries Journal, Vol. 37 No. 1, pp. 84-104, doi: 10.1080/02642069.2017.1290797.

Edvardsson, B. and Enquist, B. (2009), Values-Based Service for Sustainable Business: Lessons from IKEA, Routledge, London.

Edvardsson, B. and Enquist, B. (2011), "The service excellence and innovation model: lessons from IKEA and other service frontiers", Total Quality Management and Business Excellence, Vol. 22 No. 5, pp. 535-551, doi: 10.1080/14783363.2011.568242.

Eisenhardt, K.M. (1989), "Building theories from case study research", Academy of Management Review, Vol. 14 No. 4, pp. 532-550, doi: 10.5465/amr.1989.4308385.

Elkington, J. (1997), “The triple bottom line”, Environmental Management: Readings and Cases, p. 2.

Feng, K., Altinay, L. and Olya, H. (2019), "Social well-being and transformative service research: evidence from China”, Journal of Services Marketing, Vol. 33 No. 6, pp. 735-750, doi: 10.1108/ JSM-10-2018-0294.

Fisk, R.P., Alkire, L., Anderson, L., Bowen, D.E., Gruber, T., Ostrom, A.L. and Patrício, L. (2020), "Elevating the human experience (HX) through service research collaborations: introducing ServCollab", Journal of Service Management. doi: 10.1108/JOSM-10-2019-0325.

Fisk, R.P.P., Anderson, L., Bowen, D.E., Gruber, T., Ostrom, A., Patrício, L. and Sebastiani, R. (2016), "Billions of impoverished people deserve to be better served", Journal of Service Management, Vol. 27 No. 1, pp. 43-55, doi: 10.1108/JOSM-04-2015-0125.

Finsterwalder, J. and Kuppelwieser, V.G. (2020), "Equilibrating resources and challenges during crises: a framework for service ecosystem well-being", Journal of Service Management, Vol. 31 No. 6, pp. 1107-1129, doi: 10.1108/JOSM-06-2020-0201.

Francis, J.J., Johnston, M., Robertson, C., Glidewell, L., Entwistle, V., Eccles, M.P. and Grimshaw, J.M. (2010), "What is an adequate sample size? Operationalising data saturation for theory-based interview studies", Psychology and Health, Vol. 25 No. 10, pp. 1229-1245, doi: 10.1080/ 08870440903194015 ù.

Frow, P., McColl-Kennedy, J.R., Hilton, T., Davidson, A., Payne, A. and Brozovic, D. (2014), "Value propositions: a service ecosystems perspective", Marketing Theory, Vol. 14 No. 3, pp. 327-351, doi: $10.1177 / 1470593114534346$.

Gallan, A.S., Kabadayi, S., Ali, F., Helkkula, A., Wu, L. and Zhang, Y. (2021), "Transformative hospitality services: a conceptualization and development of organizational dimensions", Journal of Business Research, Vol. 134, pp. 171-183, doi: 10.1016/j.jbusres.2021.05.028. 
Gardiazabal, P. and Bianchi, C. (2021), "Value co-creation activities in retail ecosystems: well-being consequences", Journal of Services Marketing, Vol. ahead-of-print No. ahead-of-print, doi: 10. 1108/JSM-02-2020-0072.

Goodland, R. (1995), "The concept of environmental sustainability", Annual Review of Ecology and Systematics, Vol. 26 No. 1, pp. 1-24.

Gross, H., Schwarz, N., von Clausbruch, S.C. and Hary, K. (2021), "Art projects as transformative services to integrate refugees”, Journal of Business Research, Vol. 127, pp. 373-381, doi: 10.1016/ j.jbusres.2021.01.015.

Guido, G. (1999), Aspetti metodologici e operativi del processo di ricerca di Marketing, Cedam, Padova.

Guyader, H., Ottosson, M., Frankelius, P. and Witell, L. (2019), "Identifying the resource integration processes of green service”, Journal of Service Management, Vol. 31 No. 4, pp. 839-859, doi: 10. 1108/JOSM-12-2017-0350.

Ho, B.Q. and Shirahada, K. (2021), "Actor transformation in service: a process model for vulnerable consumers”, Journal of Service Theory and Practice, Vol. 31 No. 4, pp. 534-562, doi: 10.1108/ JSTP-04-2020-0083.

Huang, C.H. and Lin, Y.C. (2020), "Relationships among employee acting, customer-perceived service quality, emotional well-being and value co-creation”, Asia Pacific Journal of Marketing and Logistics, Vol. 33 No. 1, pp. 29-52, doi: 10.1108/APJML-04-2019-0245.

Initiative, G.R. (2013), "G4 sustainability reporting guidelines: reporting principles and standard disclosures", Global Reporting Initiative, Amsterdam, pp. 7-14.

Kuhlman, T. and Farrington, J. (2010), “What is sustainability?”, Sustainability, Vol. 2 No. 11, pp. 3436-3448, doi: 10.3390/su2113436.

Kuppelwieser, V.G. and Finsterwalder, J. (2016), "Transformative service research and service dominant logic: Quo Vaditis?”, Journal of Retailing and Consumer Services, Vol. 28, pp. 91-98, doi: 10.1016/j.jretconser.2015.08.011.

Lam, P. and Bianchi, C. (2019), "Exploring the role of family in enhancing the well-being of patients with developmental disorders", Journal of Services Marketing, Vol. 33 No. 6, pp. 721-734, doi: 10. 1108/JSM-12-2018-0365.

Lozano, R. (2008), "Envisioning sustainability three-dimensionally", Journal of Cleaner Production, Vol. 16 No. 17, pp. 1838-1846, doi: 10.1016/j.jclepro.2008.02.008.

Lubin, D.A. and Esty, D.C. (2010), "The sustainability imperative”, Harvard Business Review, Vol. 88 No. 5 , pp. $42-50$.

Luborsky, M. (1994), “The Identification and analysis of themes and patterns”, in Sankar, A. and Gubrium, J. (Eds), Qualitative Methods in Aging Research, Sage, New York, pp. 189-210.

Lucia-Palacios, L., Pérez-López, R. and Polo-Redondo, Y. (2016), "Cognitive, affective and behavioural responses in mall experience: a qualitative approach", International Journal of Retail and Distribution Management, Vol. 44 No. 1, pp. 4-21, doi: 10.1108/IJRDM-05-2014-0061.

Marshall, B., Cardon, P., Poddar, A. and Fontenot, R. (2013), "Does sample size matter in qualitative research?: a review of qualitative interviews in IS research", Journal of Computer Information Systems, Vol. 54 No. 1, pp. 11-22, doi: 10.1080/08874417.2013.11645667.

McCusker, K. and Gunaydin, S. (2015), "Research using qualitative, quantitative or mixed methods and choice based on the research", Perfusion, Vol. 30 No. 7, pp. 537-542, doi: 10.1177/ 0267659114559116.

Mollenkopf, D.A., Ozanne, L.K. and Stolze, H.J. (2020), "A transformative supply chain response to COVID-19”, Journal of Service Management, Vol. 32 No. 2, pp. 190-202, doi: 10.1108/JOSM-052020-0143.

Morelli, J. (2011), “Environmental sustainability: a definition for environmental professionals”, Journal of Environmental Sustainability, Vol. 1 No. 1, p. 2. 
Mota, B., Gomes, M.I., Carvalho, A. and Barbosa-Povoa, A.P. (2015), "Towards supply chain sustainability: economic, environmental and social design and planning", Journal of Cleaner Production, Vol. 105, pp. 14-27, doi: 10.15171/ijhpm.2014.65.

Mugion, R.G., Toni, M., Raharjo, H., Di Pietro, L. and Sebathu, S.P. (2018), "Does the service quality of urban public transport enhance sustainable mobility?”, Journal of Cleaner Production, Vol. 174, pp. 1566-1587, doi: 10.1016/j.jclepro.2017.11.052.

Murphy, P.E., Öberseder, M. and Laczniak, G.R. (2013), "Corporate societal responsibility in marketing: normatively broadening the concept”, AMS Review, Vol. 3 No. 2, pp. 86-102, doi: 10. 1007/s13162-013-0046-9.

Nasr, L. and Fisk, R.P. (2019), "The global refugee crisis: how can transformative service researchers help?”, The Service Industries Journal, Vol. 39 Nos 9-10, pp. 684-700, doi: 10.1080/02642069.2018. 1445224.

Naveed, M., Farah, M.F. and Hasni, M.J.S. (2021), "The transformative role of firm information transparency in triggering retail investor's perceived financial well-being", International Journal of Bank Marketing, Vol. 32 No. 2, pp. 190-202, doi: 10.1108/IJBM-02-2021-0068.

Noy, C. (2008), "Sampling knowledge: the hermeneutics of snowball sampling in qualitative research", International Journal of Social Research Methodology. Vol. 11 No. 4, pp. 327-344.

Ostrom, A.L., Bitner, M.J., Brown, S.W., Burkhard, K.A., Goul, M., Smith-Daniels, V. and Rabinovich, E. (2010), "Moving forward and making a difference: research priorities for the science of service", Journal of Service Research, Vol. 13 No. 1, pp. 4-36, doi: 10.1177/1094670509357611.

Ostrom, A.L., Mathras, D. and Anderson, L. (2014), "Transformative service research: an emerging subfield focused on service and well-being", Handbook of Service Marketing Research, Edward Elgar Publishing.

Ostrom, A.L., Parasuraman, A., Bowen, D.E., Patrício, L. and Voss, C.A. (2015), "Service research priorities in a rapidly changing context”, Journal of Service Research, Vol. 18 No. 2, pp. 127-159, doi: $10.1177 / 1094670515576315$.

Pawłowski, A. (2008), "How many dimensions does sustainable development have?", Sustainable Development, Vol. 16 No. 2, pp. 81-90, doi: 10.1002/sd.339.

Rahman, A. (2020), "Sources and categories of well-being: a systematic review and research agenda", Journal of Service Theory and Practice, Vol. 31 No. 1, pp. 1-33, doi: 10.1108/JSTP-01-2020-0024.

Rahman, A., Björk, P. and Ravald, A. (2020), "Exploring the effects of service provider's organizational support and empowerment on employee engagement and well-being", Cogent Business and Management, Vol. 7 No. 11767329, doi: 10.1080/23311975.2020.1767329.

Rosenbaum, M., Corus, C., Ostrom, A., Anderson, L., Fisk, R., Gallan, A., Giraldo, M., Mende, M., Mulder, M., Rayburn, S., Shirahada, K. and Williams, J. (2011), "Conceptualisation and aspirations of transformative service research", Journal of Research for Consumers, Vol. 19, pp. 1-6.

Rosenbaum, M.S., Kim, K., Ramirez, G.C., Orejuela, A.R. and Park, J. (2021), "Improving well-being via adaptive reuse: transformative repurposed service organizations", The Service Industries Journal, Vol. 41 Nos 3-4, pp. 223-247, doi: 10.1080/02642069.2019.1615897.

Ryan, R.M. and Deci, E.L. (2001), "On happiness and human potentials: a review of research on hedonic and eudaimonic well-being", Annual review of psychology, Vol. 52 No. 1, pp. 141-166, doi: 10.1146/annurev.psych.52.1.141.

Ryff, C.D. (1989), "Happiness is everything, or is it? Explorations on the meaning of psychological well-being", Journal of Personality and Social Psychology, Vol. 57 No. 6, pp. 1069-1081.

Saunders, B., Sim, J., Kingstone, T., Baker, S., Waterfield, J., Bartlam, B., Burroughs, H. and Jinks, C. (2018), "Saturation in qualitative research: exploring its conceptualization and operationalization”, Quality and Quantity, Vol. 52 No. 4, pp. 1893-1907, doi: 10.1007/s11135017-0574-8. 
Sharma, P., Kong, T.T.C. and Kingshott, R.P. (2016), "Internal service quality as a driver of employee satisfaction, commitment and performance", Journal of Service Management, Vol. 27 No. 5, pp. 773-797, doi: 10.1108/JOSM-10-2015-0294.

Sheth, J.N., Sethia, N.K. and Srinivas, S. (2011), "Mindful consumption: a customer-centric approach to sustainability", Journal of the Academy of Marketing Science, Vol. 39 No. 1, pp. 21-39, doi: 10. 1007/s11747-010-0216-3.

Shirahada, K. and Fisk, R.P. (2011), "Broadening the concept of service: a tripartite value co-creation perspective for service sustainability", Advances in Service Quality, Innovation, and Excellence Proceedings of QUIS12, pp. 917-926.

Tuzovic, S. and Kabadayi, S. (2021), "The influence of social distancing on employee well-being: a conceptual framework and research agenda", Journal of Service Management, Vol. 32 No. 2, pp. 145-160, doi: 10.1108/JOSM-05-2020-0140.

United Nations (2015), Transforming Our World: The 2030 Agenda for Sustainable Development, Department of Economic and Social Affairs, New York.

Vargo, S.L. (2011), "On marketing theory and service-dominant logic: connecting some dots", Marketing Theory, Vol. 11 No. 1, pp. 3-8, doi: 10.1177/1470593110393715.

Vargo, S.L. and Lusch, R.F. (2004), "Evolving to a new dominant logic for marketing", Journal of Marketing, Vol. 68 No. 1, pp. 1-17, doi: 10.1509/jmkg.68.1.1.24036.

Vargo, S.L. and Lusch, R.F. (2006), "Service-Dominant Logic: what it is, what it is not, what it might be", in Lusch, R.F. and Vargo, S.L. (Eds), The Service-Dominant Logic Of-Marketing: Dialog, Debate, and Directions, ME Sharpe, Armonk, NY, pp. 43-56.

Vargo, S.L. and Lusch, R.F. (2008a), "Service-dominant logic: continuing the evolution", Journal of the Academy of Marketing Science, Vol. 36 No. 1, pp. 1-10, doi: 10.1007/s11747-007-0069-6.

Vargo, S.L. and Lusch, R.F. (2008b), "Why 'service'?”, Journal of the Academy of Marketing Science, Vol. 36 No. 1, pp. 25-38, doi: 10.1007/s11747-007-0068-7.

Vargo, S.L. and Lusch, R.F. (2016), "Institutions and axioms: an extension and update of servicedominant logic", Journal of the Academy of Marketing Science, Vol. 44 No. 1, pp. 5-23, doi: 10. 1007/s11747-015-0456-3.

Venkatesh, V., Brown, S.A. and Bala, H. (2013), "Research article bridging the qualitative - quantitative divide: guidelines for conducting mixed methods”, Mis Quarterly, Vol. 37 No. 1, pp. 21-54.

Waterman, A.S. (1984), The Psychology of Individualism, Praeger, New York, NY.

WCED, S.W.S. (1987), "World commission on environment and development", Our Common Future, Vol. 17, pp. 1-91.

Wiese, A., Zielke, S. and Toporowski, W. (2015), "Shopping travel behaviour: influencing factors, shopper types and environmental consequences", International Journal of Retail and Distribution Management, Vol. 43 Nos 4/5, pp. 469-484, doi: 10.1108/IJRDM-01-2015-0006.

World Health Organization (1946), "World Health Organization: frequently asked questions", available at: http://www.who.int/suggestions/faq/en/.

World Health Organization (1997), "WHOQOL: measuring quality of life”, available at: www.who.int/ healthinfo/survey/whoqol-qualityoflife/en/.

\section{Corresponding author}

Veronica Ungaro can be contacted at: veronica.ungaro@uniroma3.it

For instructions on how to order reprints of this article, please visit our website:

www.emeraldgrouppublishing.com/licensing/reprints.htm

Or contact us for further details: permissions@emeraldinsight.com 